\title{
Effect of PWHT Temperature and Time on Hardness and Microstructure of 410NiMo Weld Metal
}

\author{
Uğur Özdemir ${ }^{1, a}$, Selçuk Keskinkılıç ${ }^{1, b}$, Filiz K. Acar ${ }^{1, c}$, Fikret Kabakci' ${ }^{2, d}$ \\ and Mustafa Acarer ${ }^{3, \mathrm{e}}$ \\ ${ }^{1}$ Gedik Welding Inc., Istanbul, Turkey \\ ${ }^{2}$ Bulent Ecevit University, Alaplı Vocational School, Alapli, Zonguldak, Turkey \\ ${ }^{3}$ Selçuk University, Faculty of Technology, Metallurgical and Materials Engineering, Konya, Turkey \\ a uozdemir@gedik.com.tr, ${ }^{\mathrm{b}}$ skeskinkilic@gedik.com.tr, ${ }^{\mathrm{c}}$ facar@gedik.com.tr, ${ }^{\mathrm{d}}$ fikretkabakci@yahoo.com \\ em_acarer@yahoo.com
}

CORRESPONDENCE ADDRESS: Uğur Özdemir, Gedik Kaynak A.Ş. Ar-Ge Merkezi Şeyhli Mahallesi, Ankara Cd. No:306, 34906 Pendik/İstanbul, Mobile: +90 5557180952 and E-mail: uozdemir@gedik.com.tr

\begin{abstract}
ASTM A743 CA6NM alloy is a martensitic stainless steel typically used in energy industry -runners and hydraulic turbine components- due to its superior toughness, yield and fatigue properties. In both the manufacturing, shielded metal arc welding is applied to join for this grade steels. However, weldability of the steels is limited due to formation of hard and brittle phases such as untempered martensite during welding and post weld heat treatment processes. The formation causes a reduction in toughness. In this study, influence of post-weld heat treatment procedure (single tempering and double tempering) and parameters on microstructure and hardness of AWS410NiMo all weld metal. Hardness tests were conducted from weld metal. Microstructures of the all weld metals subjected to different heat treatment process were characterized.
\end{abstract}

Key Words: 410NiMo, all weld metal, heat treatment, hardness, microstructure

\section{Introduction}

Low carbon $13 \% \mathrm{Cr}-4 \% \mathrm{Ni}$ (CA6NM) martensitic stainless steels such as Alloy 410 $(410 \mathrm{NiMo})$ are used at elevated temperature and corrosive environments such as hydroelectric turbine runners, chemical and power industries due to having good mechanical and corrosion properties [1, 2]. These steels have high flow stress and toughness, high resistance to cavitation and reasonable weldability. Martensitic steels with low carbon content are always quenched and tempered to have good mechanical properties [3]. A post-weld heat treatment (PWHT) is then required to temper the brittle martensite. The use of 410 NiMo steel and weld metal without PWHT is not recommended due to high level of residual stresses, cold cracking and poor fatigue resistance [3-5]. Another beneficial effect of this PWHT is to lower the residual stresses induced by welding [6]. Tempering temperature and time have a great influence on microstructure [7]. Two different tempering types were prescribed for $410 \mathrm{NiMo}$ martensitic stainless steel according to NACE MR0175 standard to acquire maximum $265 \mathrm{HB}$ hardness [8]. The aim of this study is to evaluate the influence of the applied PWHT type on microstructure and hardness of $410 \mathrm{NiMo}$ weld metal deposited by the shielded metal arc welding (SMAW) process. 


\section{Experimental}

In this study, effect of post weld heat treatment on the microstructure and hardness of $410 \mathrm{NiMo}$ weld metal was investigated. All weld metal was produced by shielded metal arc welding (SMAW) technique. A $25 \mathrm{~mm}$ thick weld metal was deposited on a $25 \mathrm{~mm}$ thick S355 JR substrate $(250 \mathrm{~mm} \times 350 \mathrm{~mm})$ using GeKa Elox B 410NiMo stick electrodes. The electrodes were fabricated by Gedik Welding Co. in Turkey. Welding parameters were given in Tab.1

Table 1. Welding parameters of produced 410NiMo All Weld Metal.

\begin{tabular}{|c|cccc|c|}
$\begin{array}{l}\text { Weld Pass } \\
\text { Number }\end{array}$ & $\begin{array}{c}\text { Preheat and } \\
\text { Inter Pass } \\
\text { Heating }\left({ }^{\circ} \mathrm{C}\right)\end{array}$ & $\begin{array}{c}\text { Current } \\
\text { (A) }\end{array}$ & $\begin{array}{c}\text { Voltage } \\
(\mathrm{V})\end{array}$ & $\begin{array}{c}\text { Weld speed } \\
(\mathrm{mm} / \mathrm{min})\end{array}$ & $\begin{array}{c}\text { Heat Input } \\
(\mathrm{kJ} / \mathrm{mm})\end{array}$ \\
\hline $\mathbf{2 5}$ & $\mathbf{1 0 0 - 1 5 0}$ & $\mathbf{1 1 0}$ & $\mathbf{3 2}$ & $\mathbf{1 2 5}$ & $\mathbf{1 . 6 8 9}$ \\
\hline
\end{tabular}

Preheat and interpass temperatures were held at $100{ }^{\circ} \mathrm{C}$ and $150{ }^{\circ} \mathrm{C}$ respectively. The weld metals were subjected to post weld heat treatment (PWHT) process as seen in Figure 1.
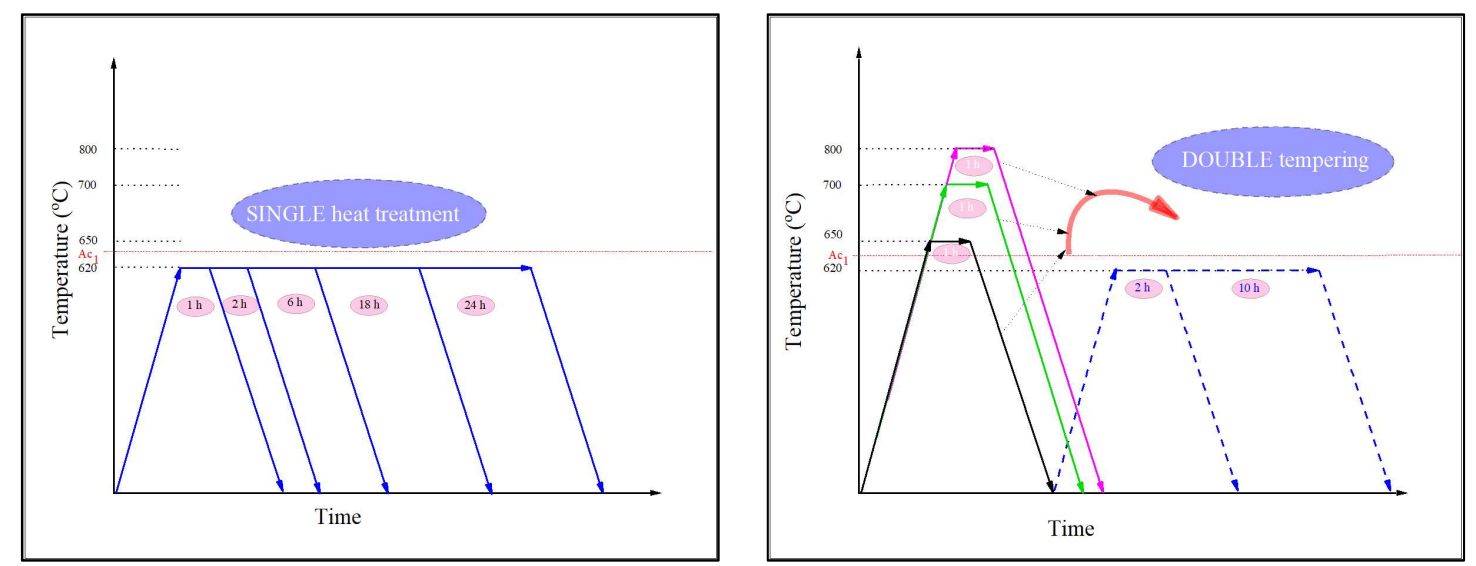

Figure 1. Systematic presentation of PWHT applied to weld metal.

Standart metallographic procedure was applied to PWHT'ed weld metal samples for microstructure characterization. Modified vilella's reagent $(2.5$ gr picric acid $+2.5 \mathrm{ml} \mathrm{HCI}+$ 95ml Ethanol) [9] was prepared as etching solution. Nikon Eclipse MA100 inverted optical microscope was employed. RIGAKU ZSX Primus II X-Ray fluorescence device and LECO CS600 were used to determine chemical composition and carbon and sulfur content respectively. Chemical analysis of weld metal is shown in the Tab. 2. Hardness' of the weld metals were measured by Brinell hardness tester $187.5 \mathrm{kgf}-\propto 2.5 \mathrm{~mm}$ ball diameter.

Table 2. Chemical analysis of weld metal.

\begin{tabular}{cccccccccc} 
& $\mathbf{C}$ & $\mathbf{M n}$ & $\mathbf{S i}$ & $\mathbf{N i}$ & $\mathbf{M o}$ & $\mathbf{C r}$ & $\mathbf{C u}$ & $\mathbf{V}$ & $\mathrm{Fe}$ \\
\hline ELOX B & & & & & & & & & \\
& 0.03 & 0.58 & 0.21 & 5.29 & 0.52 & 11.23 & 0.04 & 0.037 & Bal. \\
$410 \mathrm{NiMo}$ & & & & & & & & & \\
\hline
\end{tabular}




\section{Results and Discussion}

\subsection{Microstructure}

Figure 2 shows the microstructure of welded condition and single PWHT processes. Microstructure of welded condition has martensitic and thicker and harder than single or double PWHT'ed samples due to fresh martensite. Delta ferrite phase did not detect optical microscopy investigation. Finer martensitic structure observed $620{ }^{\circ} \mathrm{C} 18 \mathrm{~h}$ and $24 \mathrm{~h}$ PWHT. In the microstructure white area may be fresh martensite/retained austenite. Increasing tempering time, the lath and white area are finer.

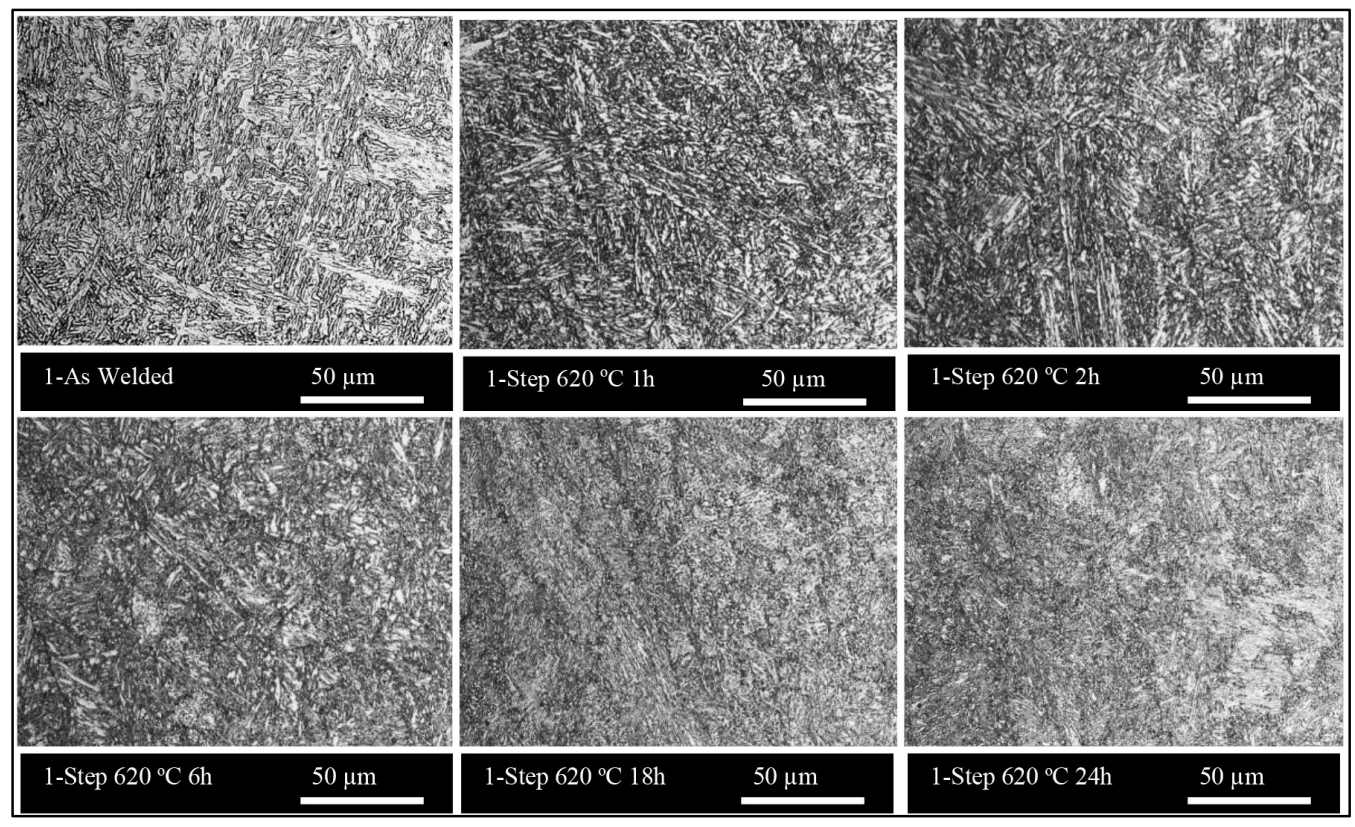

Figure 2. Microstructure of weld metal after single heat treatment processes.
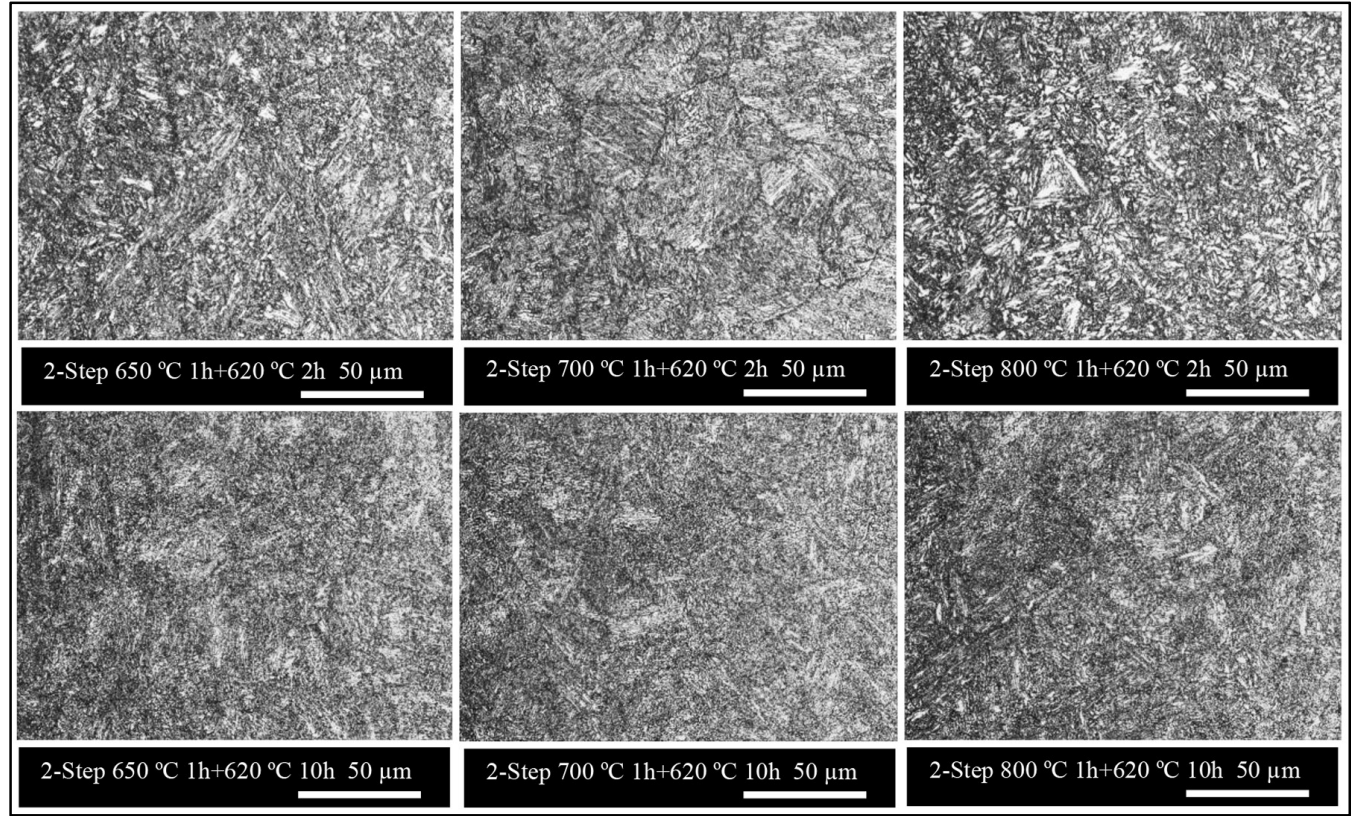

2-Step $800^{\circ} \mathrm{C} 1 \mathrm{~h}+620^{\circ} \mathrm{C} 10 \mathrm{~h} 50 \mu \mathrm{m}$

Figure 3. Microstructure of weld metal after double heat treatment processes. 
Figure 3. shows double tempered 410 NiMo weld metal. First step $650{ }^{\circ} \mathrm{C}, 700{ }^{\circ} \mathrm{C}, 800{ }^{\circ} \mathrm{C}$ applied and second step subjected to $620^{\circ} \mathrm{C} 2 \mathrm{~h}$ and $10 \mathrm{~h}$. First step temperature subjected to above the $A_{C 1}$ transformation temperature, second step below the $A_{C 1}$ temperature inhibiting hard fresh martensite. Microstructure in double tempered microstructure first step $800{ }^{\circ} \mathrm{C}$ have more blocky white area this probably retained austenite, because hardness results (Figure 4) advocating this result. Increasing tempering time from $2 \mathrm{~h}$ to $10 \mathrm{~h}$ finer microstructure observed. 410NiMo martensitic stainless steel starts to solidification as $\delta$ ferrite. $\delta$ ferrite transforms to $\gamma$ austenite above $1200{ }^{\circ} \mathrm{C}$ and fully transforms to $\gamma$ austenite at $1200{ }^{\circ} \mathrm{C}$. Austenite will transform to martensite. Then martensitic microstructure occurs after cooling room temperature $[5,10]$. The sequence of the transformation was presented by [5] as below:

$$
\mathrm{L} \rightarrow \mathrm{L}+\mathrm{Fp} \rightarrow \mathrm{Fp} \rightarrow \mathrm{Fp}+\mathrm{A} \rightarrow \mathrm{A} \rightarrow \text { Martensite }
$$

During solidification, alloying elements segregation can form between dendrites. Therefore $\delta$ ferrite can remain in the microstructure at room temperature. Retained austenite can also may remain between martensite laths [10].

\subsection{Hardness}

Hardness results are shown in Figure 4 while hardness is $350 \mathrm{HB}$ as welded condition, the hardness decreased with increasing tempering time at $620{ }^{\circ} \mathrm{C}$ in the single heat treatment process. In double tempering process, the samples tempered at $620^{\circ} \mathrm{C}$ for $10 \mathrm{~h}$ have the lowest hardness. The results agree with literature $[11,12]$. Furthermore, the hardness limit for UNS S41425 steel is $265 \mathrm{HB}$ according to NACE 0175/ISO 15156. In this study, the limit was achieved in double tempering process. It can be concluded that double tempering causes considerable effect softening of martensite [12].
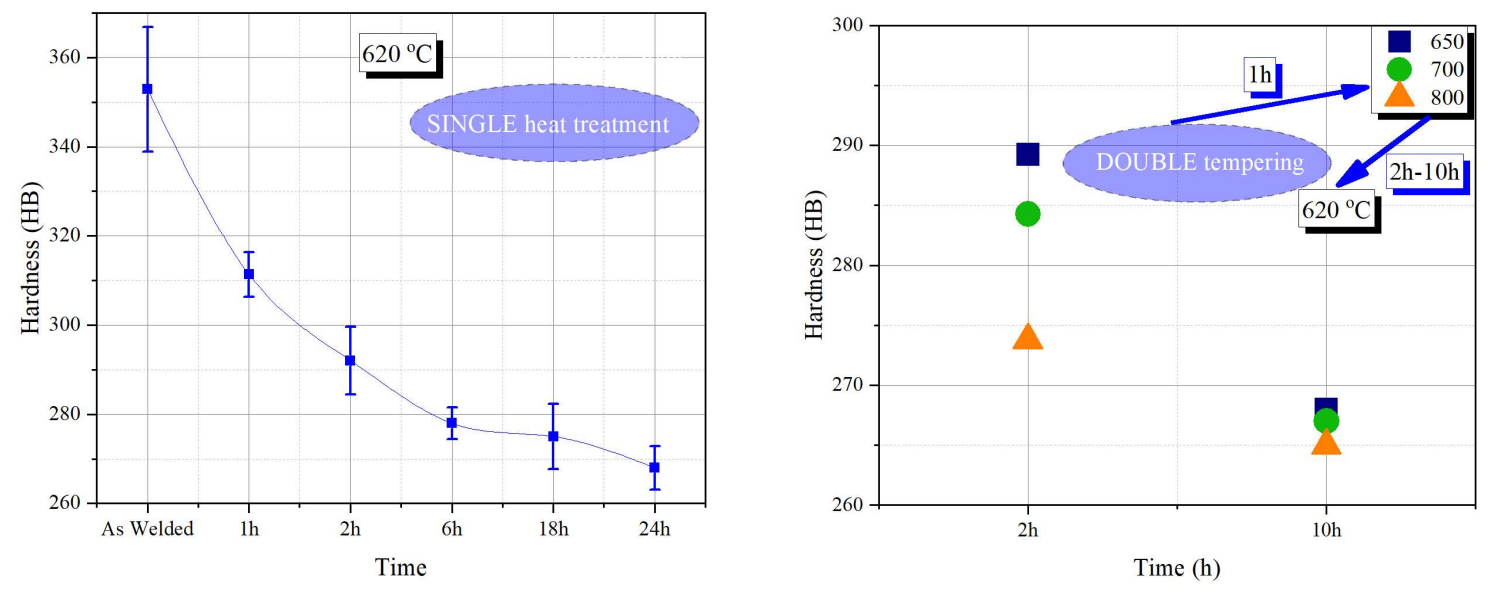

Figure 4. hardness results of 410NiMo weld metal after single and double heat treatment processes.

\section{Conclusion}

The effect of post-weld heat treatment temperatures on microstructure and hardness was investigated in the present study. Following conclusions could be drawn from this study;

1. Microstructure as welded condition has martensitic and did not detected delta ferrite phase by optical microscopy investigation. 
2. Microstructures of Single heat treatment $620^{\circ} \mathrm{C} 1 \mathrm{~h}, 2 \mathrm{~h}$ and $6 \mathrm{~h}$ have martensitic and may be some retained austenite/fresh martensite and thicker than $620^{\circ} \mathrm{C} 18 \mathrm{~h}$ and $24 \mathrm{~h}$.

3. Microstructures of double tempering finer structure detected $620^{\circ} \mathrm{C} 10 \mathrm{~h}$.

4. Increasing tempering time $\left(620^{\circ} \mathrm{C}\right)$ reduced hardness.

5. First heat treatment temperature in DOUBLE tempering hardness effected by temperature, lower hardness determined higher first temperature.

Double tempering is vital for welded martensitic stainless steels due to hardness.

\section{Acknowledgement}

The authors would like to show their gratitude to Gedik Welding Inc. for providing welding consumables and facility use.

\section{References}

[1] R.R.de Gouveia, A.G.M. Pukasiewicz, A.R. Capra, S.L. Henke, P.C. Okimoto: Effect of interpass temperature on microstructure, impact toughness and fatigue crack propagation in joints welded using the GTAW process on steel ASTM A743-CA6NM,Welding International, 29(6) (2015), pp. 433-440.

[2] H.-J. HUTH: Fatigue design of hydraulic turbine runners, , 178p. Tese (Doutorado)Department of Engineering Design and Materials, Norwegian University of Science and Technology, Trondheim, Norway (2005), pp.178.

[3] P.Bilmes, , M. Solari, C. Llorente: Characteristics and effects of austenite resulting from tempering of $13 \mathrm{Cr}-\mathrm{NiMo}$ martensitic steel weld metals, Materials Characterization, 46(4) (2001), pp. 285-296.

[4] S.Godin, E. Boudreault, J.B. Lévesque, B. Hazel: On-site post-weld heat treatment of welds made of 410NiMo Steel, Proceedings of MS\&T-COM, Montreal, Quebec, Canada (2013), pp.754-765.

[5] D. Kotecki, J. Lippold: Welding metallurgy and weldability of stainless steels, Wiley, (2005), pp.64,188-206.

[6] D.Thibault, P.Bocher, M.Thomas, M. Gharghouri, M. Côté: Residual stress characterization in low transformation temperature $13 \% \mathrm{Cr}-4 \% \mathrm{Ni}$ stainless steel weld by neutron diffraction and the contour method, Materials Science and Engineering: A, 527(23) (2010)pp. 6205-6210.

[7] G.Krauss: Steels: Processing, Structure and Performance, ASM International, Materials Park, OH, (2005), pp. 251-262.

[8] ISO15156: 2009 "Petroleum and natural gas industries-Materials for use in H2Scontaining Environments in oil and gas production", NACE International, (2001) 1440.

[9] J.Onoro: Martensite microstructure of 9-12\% Cr steels weld metals, Journal of Materials Processing Technology, 180(1-3) (2006), pp. 137-142.

[10] M.M. Amrei, H.Monajati, D.Thibault, Y.Verreman, L. Germain, P. Bocher: Microstructure characterization and hardness distribution of $13 \mathrm{Cr} 4 \mathrm{Ni}$ multipass weld metal. Materials Characterization, 111(2016), pp. 128-136.

[11] M.Divya, C.Das, V. Ramasubbu, S.Albert, A.Bhaduri: Improving 410NiMo weld metal toughness by PWHT. Journal of Materials Processing Technology, 211(12) (2011)p. 20322038.

[12] S. Tavares, B.Almeida, D. Corrêa, J.Pardal: Failure of super $13 \mathrm{Cr}$ stainless steel due to excessive hardness in the welded joint. Engineering Failure Analysis, 91 (2018), pp. 92-98. 